\title{
The Emotional Competence of Women Teachers With Reference To Their Social Background
}

\author{
Dr. M.A. Khalique ${ }^{1}$ and Manisha Digambarrao Asore ${ }^{2}$ \\ ${ }^{1}$ Research Guide, Dr. Babasaheb Ambedkar Marathwada University, \\ Aurangabad, India \\ ${ }^{2}$ Research Student, Dr. Babasaheb Ambedkar Marathwada University, \\ Aurangabad, India
}

\begin{abstract}
This study explores the relationship between Emotional Competence of women teachers and their social background.

For this 400 women teachers working in different secondary schools of Aurangabad district were selected as sample of this study by following stratified random sampling. The data has been collected with the help of Emotional Competence scale constructed by H.C. Sharma and R. Bharadwaj. The collected data was analyzed by using chi-square and Phi-coefficient.

The results indicated that there is significant difference among emotional competence of women teachers with reference to their social background and there is significant relationship between emotional competence and social background of women teachers.
\end{abstract}

Key words: Emotional Competence, women, Teachers, Social Background etc.

\section{Introduction}

There is a Healthy mind dwells in a Healthy bodyAnonymous

As we know, the relation between Mind and Body is symbiotic in nature. Every individual is considered as completely healthy only when he/she is physically as well as mentally healthy. In today's era of Technology and fast-track life style, everyone tries to live and lead a healthy life. For this, everyone needs to maintain their physical, mental and emotional and social balance by making some extra efforts. It needs certain competencies one of those are emotional competencies. We can say that emotional competence is an ability of an individual to deal with various emotions related to his social and cultural life, and it is needed to perform successfully at work. Emotional competence can be acquired or learned to improve one's performance (Sharma H.C. \& Bhardwaj, R.1995). It means being emotionally competent meant to be more stable and confident to deal with various emotions aroused during various situations whether those are favorable or unfavorable.

Pertaining to these facts, the women teachers working in secondary schools are role models for upcoming generations. Those generations learn from their teachers about emotions and their control while observing the behavior of their teachers and particularly women teachers. The secondary school students also have change in behavior due to their adolescence period and have many problems while dealing with emotions (Sheela, M.1992). For handling of such students with proper care and proper emotional and moral support, teachers should possess emotional competencies so that they can shape the minds of future generations.

In India, most of the working women worked as teachers in primary and secondary schools (Maitra, J.1997, Rao, D.B.\& et.al.2000). It is observed that the teaching job is considered as most suitable job for women (Lalithadevi,U.1982, Talwar,U.1984). Women teachers play dual roles in family and at school. While dealing with different roles and different situations with different people, women teachers efficiently handle every situation with proper emotional and moral balance. Apart 
from this, women teachers belong to different social background have different emotional set up, and each women teacher has her own unique way of handling a difficult situation whether at home or at school. This made the researcher to study about the emotional competence of women teachers with reference to their social background.

\subsection{Objectives}

The objectives of the study were-

1. To find out the emotional competence of women teachers.

2. To compare the emotional competence of women teachers with respect to their social background.

3. To find out the relationship between emotional competence and social background of women teachers.

\subsection{Hypothesis}

1. There is significant difference among emotional competence of women teachers with respect to their social background.

2. There is significant relationship between emotional competence and social background women teachers.

\section{Materials and methods}

2.1 Research method: considering the problem under study, the researcher used descriptive survey method.(Best,J.W.\& Kahn,J.V.2005)

2.2 Sample and sampling method: The stratified sampling method was used to select 400 women teachers working in secondary schools in Aurangabad district.(Hakim,C.1987;Chandrakandan,K.\&Ka rthikeyan,C.2004)

2.3 Material: The Emotional competence scale standardized by H. C. Sharma and R. Bhardwaj was used to collect data.

2.4 Statistics used: Inferential statistics chisquare and Phi-coefficient was used for data analysis.

\section{Analysis and Interpretation}

The data was analyzed to study the difference among emotional competence of women teachers with respect to their social background with help of chi-square.

\subsection{Calculation of Chi-Square for Emotional Competence V/s Social Background of Women Teachers}

Table No. 1

Chi-Square values for Emotional Competence V/s Social Background of Women Teachers

\begin{tabular}{|c|c|c|c|c|c|}
\hline $\begin{array}{l}\text { Cel } \\
1 \\
\text { No. }\end{array}$ & $\begin{array}{l}\text { Observed } \\
\text { Frequenc } \\
\text { y 'O' }\end{array}$ & $\begin{array}{l}\text { Expected } \\
\text { Frequenc } \\
\text { y 'E' }\end{array}$ & $\mathrm{O}-\mathrm{E}$ & $(\mathrm{O}-\mathrm{E})^{2}$ & $\begin{array}{l}(\mathrm{O}- \\
\mathrm{E})^{2} / \mathrm{E}\end{array}$ \\
\hline $\mathrm{a}$ & 28 & 14.575 & $\begin{array}{l}13.42 \\
5\end{array}$ & 180.23 & $\begin{array}{l}12.36 \\
5\end{array}$ \\
\hline b & 18 & 28.62 & -10.62 & $\begin{array}{l}112.784 \\
4\end{array}$ & 3.940 \\
\hline $\mathrm{c}$ & 7 & 9.805 & -2.805 & 7.868 & 0.802 \\
\hline d & 30 & 20.35 & 9.65 & 93.1225 & 4.576 \\
\hline $\mathrm{e}$ & 35 & 39.96 & -4.96 & 24.6016 & 0.615 \\
\hline $\mathrm{f}$ & 9 & 13.69 & -4.69 & 21.9961 & 1.606 \\
\hline $\mathrm{g}$ & 10 & 28.325 & $\begin{array}{l}- \\
18.32 \\
5\end{array}$ & 335.805 & $\begin{array}{l}11.85 \\
5\end{array}$ \\
\hline $\mathrm{h}$ & 82 & 55.62 & 26.38 & $\begin{array}{l}695.904 \\
4\end{array}$ & $\begin{array}{l}12.51 \\
1\end{array}$ \\
\hline $\mathrm{i}$ & 11 & 19.055 & -8.055 & 64.883 & 3.405 \\
\hline $\mathrm{j}$ & 26 & 30.25 & -4.25 & 18.0625 & 0.597 \\
\hline $\mathrm{k}$ & 49 & 59.4 & -10.4 & 108.16 & 1.820 \\
\hline 1 & 35 & 20.35 & 14.65 & $\begin{array}{l}214.622 \\
5\end{array}$ & $\begin{array}{l}10.54 \\
6\end{array}$ \\
\hline $\mathrm{m}$ & 16 & 16.5 & -0.5 & 0.25 & 0.015 \\
\hline $\mathrm{n}$ & 32 & 32.4 & -0.4 & 0.16 & 0.004 \\
\hline \multirow[t]{2}{*}{ o } & 12 & 11.1 & 0.9 & 0.81 & 0.072 \\
\hline & & & & & $\begin{array}{l}64.72 \\
9\end{array}$ \\
\hline
\end{tabular}

Chi Square $\chi^{2}=\sum \frac{(O-E)^{2}}{E}$---Equation (1)

$$
\chi^{2}=64.729
$$

Calculation of degrees of freedom $\mathrm{df}=(\mathrm{C}-1)(\mathrm{R}-1)$------Equation $(2)$ where,

$$
\begin{aligned}
& \mathrm{df}=\text { Degrees of freedom } \\
& \mathrm{C}=\text { Number of columns }=5
\end{aligned}
$$




$$
\begin{aligned}
& \mathrm{R}=\text { Number of rows }=3 \\
\therefore \quad \mathrm{df} & =(5-1)(3-1) \\
\mathrm{df} & =4 \times 2 \\
\mathrm{df} & =8
\end{aligned}
$$

The table value of chi-square for $\mathrm{df}=8$ is 20.09 at 0.01 of significance.

Whenever the calculated chi-square value is greater than the table value of chi-square then the null hypothesis is rejected and the directional hypothesis is accepted.

Here, the calculated chi-square value is 64.729 and the table value of chi-square for $\mathrm{df}=8$ is 20.09. Thus the calculated chi-square is much greater than its respective table value. Therefore, the null hypothesis $\mathrm{H}_{1}$ is rejected.

\subsection{Calculation of Phi-Coefficient of Correlation for Emotional Competence V/s Social Background of Women Teachers:-}

Phi-Coefficient $\phi=\sqrt{\frac{x^{2}}{N}}$----Equation (3)

Where, $x^{2}=$ Chi-square value

$\mathrm{N}=$ total number of respondent in sample Here,

$x^{2} \quad=$

$=64.729[$ From Table No. 1]

$\begin{array}{rll}\mathrm{N} & = & 400 \\ \therefore \quad \phi & = & \sqrt{\frac{64.729}{400}} \\ \frac{\phi}{\sqrt{0.1618225}} & =\end{array}$

$\phi \quad=$

0.402

Comparing this value according to the range of coefficient, we can find out the nature of relationship between the emotional competence of women teachers and their social background.

\section{Results and Discussion}

As the calculated chi-square value is greater than its respective table value, the null hypothesis $\mathrm{H}_{1}$ is rejected and it is concluded that there is significant difference among the emotional competence of women teachers according to their social background. It reveals that the social background affects the emotional competence of women teachers.
From the calculated value of chi-square for finding the difference among the emotional competence of women teachers according to their social background, the researcher has calculated phi-coefficient for finding the relationship between the emotional competence and social background of women teachers.

Table No. 2

Nature of Relationship According to Coefficient Range

\begin{tabular}{|l|l|}
\hline Coefficient Range & Nature of Relationship \\
\hline $0.90-1.00$ & Very strong \\
$0.70-0.90$ & Strong \\
$0.40-0.70$ & Substantial \\
$0.20-0.40$ & Weak \\
Less than 0.20 & Negligible \\
\hline
\end{tabular}

(Garret,H.E.1962;

Wilkinson,T.S.\&

Bhandarkar,P.L.2005)

As the value of phi-coefficient for the relationship between the age and the emotional competence of women teachers is 0.402 which shows that there is positive and substantial relationship between these two variables. The phicoefficient value shows that there is positive and substantial relationship between the emotional competence of women teachers and their social background. Hence the directive hypothesis $\mathrm{H}_{2}$ is accepted. It means that as the social background of women teachers is enhanced, it also helps to improve their emotional competence level.

\section{Conclusion}

Every individual works for earning as well as enhancing his socio-economic status. While working outside the family, most of male workers get support from their families (Naik, S.\&Nair,J.2005, Buch,M.B.1979).

Whenever a woman works outside the family, she has to work for family members by accomplishing daily chores in household and then work for earning. This makes a hectic work schedule for most of the working women. In this the social background of the family of working women contributes a lot by making a support system for working women(Aggarwal,J.C.1976; Anant,S.\&et.al1986 ;Jain,S.1988). This includes the help in household work and giving leisure time for women herself by extending help in house work by keeping maids. By doing these little efforts, we can made the working women stress free which 
could give rise to emotionally competent women at workforce and this would contribute a lot in nations progress.

\section{References}

1.] Aggarwal, J.C., Indian Women: Education \& Status, Arya Book Depot, New Delhi, (1976).

2.] Anant, S., Rao, S.V.R. \& Kapoor, K., Women at Work in India - A Bibliography, Sage Publications, New Delhi, (1986).

3.] Best, J.W. \& Kahn, J.V., Research in Education $\left(10^{\text {th }}\right.$ ed.), Prentice - Hall of India Pvt. Ltd., New Delhi, (2005).

4.] Buch, M.B. (Ed.)., Second Survey of Research in Education-1972-78, Centre of Advanced Studies in Education, Bhopal, (1979).

5.] Chandrakandan, K. \& Karthikeyan, C., Behavioural Research Methodology, Classical Publishing Company, New Delhi, (2004).

6.] Garret, H.E., Statistics in Psychology \& Education, Allied Pacific Pvt. Ltd., Bombay, (1962).

7.] Hakim, C., Research Design, Allen and Uncoin Publishers, London, (1987).,

8.] Jain, S., Status and Role Perception of Middle Class Women, Puja Publishers, New Delhi: (1988).
9.] Lalithadevi, U., Status \& Employment of Women in India, B.R. Publishing Corporation, Delhi, (1982).

10.] Maitra, J. (Ed.), Women \& Society: Equality \& Empowerment, Kanishka Publishers \& Distributors, New Delhi, (1997).

11.] Nayak, S. \& Nair, J., Women's Empowerment in India, Pointer Publisher, Jaipur, (2005).

12.] Pruthi, R.K. \& et.al. (Eds.). Status \& Position of Women in Ancient, Medieval \& Modern India, Mangal Deep Publications, Jaipur,(2001).

13.] Rao, D.B. \& et.al., Status \& Advancement of Women, APH Publishing Corporation, New Delhi, (2000).

14.] Sharma H.C. \& Bhardwaj, R., Manual for the Scale of Emotional Competencies. Mapan , Agra, (1995).

15.] Sheela, M., Professional Behaviour of Teachers. The Indian Publications, Ambala Cantt., (1992).

16.] Talwar, U., Social Profile of Working Women. Jain Brothers, Jodhpur, (1984).

17.] Wilkinson, T.S. \& Bhandarkar, P.L., Methodology and Techniques of Social Research (16 ${ }^{\text {th }}$ ed.), Himalaya Publishing House, Mumbai,

(2005). 